\title{
The Potential Capacity of Hamlets: Comparative Research on Small European Municipalities ${ }^{1}$
}

\author{
Michiel S. de Vries \\ Radboud University, Department in Public Administration, The Netherlands \\ m.devries@fm.ru.nl \\ https://orcid.org/0000-0001-6827-2852 \\ Iwona Sobis \\ Gothenburg University, The School of Public Administration, Sweden \\ iwona.sobis@spa.gu.se \\ https://orcid.org/0000-0003-0196-8454
}

Received: 4. 1. 2019

Accepted: 1. 3. 2019

\section{ABSTRACT}

The main theories on small municipalities and the practices as seen in many a country involving the consolidation thereof presume that the contextual and structural conditions under which small municipalities have to perform work to their detriment and pose a threat to their viability. However, the institutional and human resource conditions in which small municipalities operate might work both ways, being profitable as well as disadvantageous. This paper investigates what is theoretically known and can be empirically deduced about the capacity of small municipalities in Europe. The conclusion is that existing research is inconclusive in its outcomes regarding the actual capacity of so-called hamlets and that existing data related to local capacity are unfit to measure such among these small municipalities. Nonetheless, the paper concludes that although no conclusions can be drawn on the actual capacity of small municipalities, their potential capacity is significant. This is concluded based on their legal protection, their inclination to focus on a limited number of policy areas, their access to central and regional decision-making, and especially the trust they receive from their residents.

Keywords: capacity, conditions, hamlets, small municipalities, performance, trust

JEL: H11, H77

1 This article is a revised version of the paper entitled 'The Capacity of Hamlets' presented at the 26 $6^{\text {th }}$ NISPAcee Annual Conference 2018: "Public Administration for Well-being and Growth", Iasi, Romania, 24-26 May 2018. The NISPAcee contributions are not publicly available. 


\section{Introduction}

In many European countries a tendency to amalgamate small municipalities is visible. This is done because of its supposed positive effects on the capacity and democracy of the involved local governments (cf. de Vries and Sobis, 2013). This paper challenges those practices by asking what is known from existing research about the capacity of small municipalities and whether it is really so problematic as policymakers in several countries want us to believe. The recent book by Denters, Goldsmith, Ladner, Mouritzen and Rose (2014) on "Size and Local Democracy" concludes that the expected relation is at least ambiguous as far as democracy is concerned. Their findings show first of all that the size of a municipality is not linearly, but curve-linearly related to the quality of its democracy and capacity, and secondly that the sign of that relation is negative instead of positive. They conclude: "the size of the local political system has a significant negative effect on the character of local democracy in about half of the models estimated. Where we find such effects, however, they are relatively weak and are most pronounced in the smallest municipalities" (Denters et al., 2014, p. 315). As they put it themselves, their overall conclusions are more in conformity with the "lovely Lilliput argument" implying that small is beautiful, than with the 'big is beautiful' argument.

The findings beg the question whether something similar can be concluded regarding the capacity of small municipalities, villages or hamlets. The arguments Denters et al., (2014) themselves provide are twofold. From the citizen's point of view, small size enables widespread public participation, and because everybody knows everybody, social relations in such small communities are characterized by more social cohesion, and more social capital. Citizens have more say in small municipalities. From a governance perspective, small size enables responsiveness, because of the multiplicity of - informal as well as formal - channels available to the public officials to keep in contact with the citizenry, while large-scale bureaucracies need to depend on hierarchy and formalism.

This рарег explores this issue further, giving an overview of existing theoretical and new empirical findings about the capacity of hamlets. Denters et al., (2014) restricted their research to the analysis of public perceptions and indicators of direct and indirect democracy. This paper intends to give a twofold supplement to their research. First, on theories on the capacity of governance in small systems of law. Second, on outcomes of empirical analyses on the capacity of small municipalities.

In order to answer the question of what is known from existing research about the capacity of small municipalities? The following sub-questions are subsequently addressed:

- What is local government capacity and which dimensions need to be distinguished?

- What is expected in theory about the impact of size on local capacity? 
- What trends emerge out of case studies on small municipalities?

- What can be concluded about the local capacity of small municipalities analyzing comparative data?

This research is triggered by the findings of Denters et al., (2014) although that research mainly focused on democracy and less on the capacity of small municipality's governance. The famous Dahl-Tufte (1973) dilemma tells, however, that the two are related. While local democracy could diminish when the scale of a municipality increases, its capacity is expected to increase. When it is found that there are indeed indicators that local government's democracy is not linearly related to increasing scale, one wonders whether capacity is positively and linearly related to increasing scale. This paper is to be seen as a supplement to their analyses as it investigates what is known theoretically and empirically about capacity issues in the governance of hamlets. Are there theoretical and empirical indicators that support the idea that not only with regard to local democracy but also to capacity, "small is beautiful"?

The next paragraph gives an overview of theories on the capacity of the governance of municipalities and the supposed merits of size. Subsequently, we will give an overview of existing empirical studies on small municipalities and the contents of local capacity indexes and the criteria used therein. We continue with a secondary analysis on new data and end with a discussion and conclusion regarding the main question.

\section{Theories on the capacity of municipalities}

Capacity in general is defined by the UN as "the ability of individuals, institutions and societies to perform functions, solve problems, and set and achieve objectives in a sustainable manner" (UN 2012, p. 56). The World Bank sees it as "the ability to access and use knowledge and skills to perform a task and to act in pursuit of an objective" (ibid. p. 56). The elaborations surrounding these definitions tell that appropriate organizational structures, systems and resources have to be in place for public institutions to operate effectively, and more importantly staff have to have the ability to understand goals and objectives in order to deliver on predetermined goals.

Local government capacity can also be defined as "the ability of local government to perform their functions in an effective and efficient way" (cf. Reddy, Nemec, and de Vries (2015, p. 161). Reddy et al., (2015, p. 162) distinguish four determinants of such local capacity, namely (1) contextual, (2) structural, (3) institutional, and (4) human resource conditions.

Contextual conditions are found in the jurisdiction, the socio-economic situation of the municipality involved, historical determinants, et cetera. As to historical context, the emerging welfare state is said to have put additional burdens on, especially, small municipalities (Kjellberg, 1985). The increasing number of functions for the public sector, resulted also in the increased importance of local government. It obtained increased power and authority and was seen as the governmental layer in which everything was to be implement- 
ed. This created pressures on especially small municipalities. A second development is the increasing urbanization, making the position of especially small and rural municipalities difficult in their relation to their larger expanding urban neighbors (Brans, 1992). A third development is seen in the distrust of national politicians towards the capacity of municipalities and especially the small ones. Those politicians doubt whether municipalities can deliver the services and goods deemed necessary by themselves and talk about the need for efficiency, rationalization, customer-friendly service, flexibility, local control and development, and modernizing social services. They often pursue economies of scale, better service provision, distributional equity, local economic development, and strengthened local democracy (cf. Wollmann, 2004; 2012) through amalgamations. They tend to argue - similarly as the World Bank that larger governments are able to provide services at lower unit or per capita costs or deliver better quality services at the same cost by capturing economies of scale. Alternatively, indivisibilities in production, which are most likely to arise for very small units of government, can be offset with a larger scale (cf. Fox and Gurley, 2006, p. 8). However, this might vary for different policy areas. Services entailing large capital costs might need a larger size than labor intensive services and in general Fox and Gurley conclude that: "bigger does not always imply lower costs and can imply higher costs" (2006, p. 35).

The position of small municipalities can become challenging under such changing contextual conditions. They need to provide more services, their spacious rural areas are enviously looked upon by their big urban neighbors who lack to space to expand, and their capacity to perform is increasingly put into question by higher-level politicians and administrators. The resulting question is to which extent small municipalities are protected in their existence given these contextual developments, which sometimes do and sometimes don't force them to merge. In some countries, they are protected through the constitution, whereas in other countries they are not, and amalgamation processes therefore are possible and more likely.

Structural conditions refer to the position of local government vis-à-vis other governments, in terms of the degree of decentralization, the delegation of tasks that local governments are responsible for, and their financial autonomy. Countries vary to the degree they give the same powers and authorities to small and large municipalities, whether autonomous and delegated tasks are given to all municipalities or only to larger municipalities, and how supervision of municipalities is arranged. In some Western countries, all municipalities have the same tasks irrespective of their size, but this needs not be the case. If municipalities are too small to handle decentralized tasks on their own, they can cooperate or can be forced to cooperate, as is the case in France with its inter-municipal groupings.

This condition is often said to be related to "economies of scale" (Boyne, 1995). Researchers expect positive scale effects as large entities can produce with lower average costs per unit than small ones. This is the case because there are always fixed costs, which with increasing size are spread over different units 
and thus become lower per unit. A municipality, no matter how big or small, needs a mayor and a council. The relative costs thereof per unit of goods or services delivered are said to decrease, if the number of those units increases. A counter-argument is that mayors of small municipalities as the heads of the local government have to do everything; from planning to implementing projects and the fixed costs are relative as there is less division of labor (Tatar, 2010, p. 211). Bhatti and Hansen (2011) found that an increase in jurisdiction size leads to lower administrative costs per capita that can be substantial.

Institutional conditions refer to the internal organization, the financial situation (budget), the availability of a robust database on key economic variables, personnel, financial management, and the quality of the infrastructure. Wallis and Dollery (2002, p. 79) emphasize the importance of such institutional capacity, that is, local government's ability to effectively uphold authority and the regulation of economic and political interactions. The assumption is that small local governments are in general too weak to implement policies effectively (Lorvi, 2013). This applies, for instance, to auditing practices. Recently, the auditors from the Council of Europe concluded that concerning the frequency of external auditing: "Inevitably the situation was worse in countries with large numbers of small authorities (only 84 out of 7,455 the Romanian local government final accounts had been audited)" (Davey, 2012, p. 73). The same report also warns for the quality of the drafting of tax regulations, particularly in small municipalities (p. 137).

On the other hand, one could also say that small municipalities have an advantage in institutional terms. As distances are small, it may be assumed that there is a high level of what is known as "ordinary knowledge". People in small municipalities know each other i.e., there is a large quantity of self-evident information. The existence of small distances means that it is virtually impossible to formulate policies without involving the target group in this process. A high degree of accessibility of the public administration is expected as regards involving people in the development of policy and involving the business community in the development of policy. A high degree of transparency and timeliness, understandability, correctness, and completeness of information provided may also be expected. A high level of "ordinary knowledge" means that there is much self-evident knowledge of citizens and companies and events that occur (Lindblom and Cohen, 1979, p. 12-14). People are closely related to one another as they are family or neighbors, went to the same school, have common friends and acquaintances, and because everything that takes place in the micro-environment and every important development is immediately known. This means that many things can be done based on implicit knowledge, informal relationships, and without extensive bureaucratic formalities, and that considerably more improvisation and creativity is possible than in a larger municipality with a more extensive bureaucracy. Small distances imply that the quality of the information provision is automatically adequate, and that the relationships are informal. The surplus of ordinary knowledge means that the bureaucracy in small municipalities may be expected to be less. 
Ordinary knowledge, informal relationships, and a "like-knows-like" mentality do have their advantages when avoiding excessive bureaucracy, but they also have a drawback, because decisions can be made that are not entirely in accordance with the rules. Small distances have their advantages, because buyers and sellers know each other, entrepreneurs and public servants know each other, but the risk is that public and private interests become mixed, that, through bribes or even corruption. Sometimes issues are handled by private actors, contrary to legislation and regulations, and public matters are arranged quickly by public actors only in case of bribes and personal compensation. In large jurisdictions, it is often impossible for individual public servants to accelerate the processing of a request or a permit application. The possibility to accelerate a process of handling a request rather seems more probable in a micro jurisdiction as a small municipality.

Human resource conditions refer to the quality of leadership, the availability of skills in economic and policy analysis, in budgeting, financial management, auditing, evaluation and procurement. Carter (2013, p. 2) talks about a human resource structure enabling "five pillars of strength": (1) a structure that is strong regarding ethical governance, (2) it has the required authority to identify local problems and find local solutions, (3) it facilitates local economic development through community engagement, (4) it is technically able to build and maintain a database and knowledge to respond to community and business needs, and finally, (5) it has a skilled staff, and effective long-term financial and asset management.

Typical of small municipalities is that there usually are a relatively small number of public servants. This means that the characteristics of Weber's model for bureaucracy cannot completely apply. Because of the small number of people, it is likely that the tasks of an official are not limited by the job description, but that these tasks are rather determined by the official's background, education, opinions, and preferences. To quote Murray: "[In such micro jurisdictions] in many jobs the work done, and the whole character of the job, is fashioned by the individual job holder. Rather than the individual being molded to a defined job, the job is molded to suit the individual" (1981, p. 95). In the literature, such small workforces are seen as problematic. In Local Capacity Indexes, it is seen as an indication that robustness is lacking.

In addition, in small municipalities adequate training and education for officials are often lacking. Often there is relatively little supervision of individual decisions, i.e. lacking checks and balances, lacking possibilities to appeal about a decision, and the political influence on official decisions is relatively large (Kersell, 1987). This seems to derogate adequate policy development, because the government officials probably meet classic characteristics, such as effectiveness and efficiency, expertise, quality, and enforcement of legislation and regulations, to a lesser extent.

As a result, the Council of Europe argues that one of the key challenges for municipalities in Europe is the continuing weakness of performance audit, particularly in countries with large numbers of small municipalities without 
qualified personnel (Davey, 2012, p. 36). Also, single national studies argue that the number of personnel is directly related to capacity. To quote Haček and Bačlija (2009):

If the levels of administrative capacity are compared with the sizes of municipalities (according to the number of inhabitants), a conclusion can be drawn that small municipalities (with up to 5000 inhabitants) tend to have either a medium or a lower level of administrative capacity, and larger ones (with over 5000 inhabitants) have a middle to high level of administrative capacity (p. 324).

A preliminary conclusion is that the four conditions in theory have several implications for our expectations about the way policies are made in small municipalities. The dynamics in contextual conditions pose a threat to the viability of small municipalities. The changing structural conditions add to this threat, as the - sometimes enforced - cooperation, horizontally with other municipalities, and vertically with regional and national government is detrimental for the autonomy of small municipalities. Considering the institutional and human resource conditions of small municipalities, policy processes in hamlets are different from those in large municipalities and perhaps of less quality in terms of due process, but not necessarily of lower quality. The reason is the abundance of ordinary knowledge, the informal base, and subsequently tailor-made way, in which services can be provided, and the minimum of bureaucracy, might well balance the possibly deficient expertise in some areas, the substandard meticulousness with which decisions are made, and lacking care for procedural aspects thereof.

These preliminary observations make it interesting to research the impact of the four conditions on the capacity of small municipalities. The hypothesis steering that analysis and derived from the theoretical analysis is that small municipalities are expected to have a lower capacity than big municipalities.

In the next section we will describe how we will test this hypothesis, what data are used and what kind of indicators, and in the subsequent section the outcomes of that test will be presented.

\section{Findings on the capacity of small municipalities}

In this section we give an overview of the outcomes of existing case-studies on the capacity of small municipalities as found in the scholarly literature. We sought, using the University Libraries of Gothenburg and Nijmegen, Google Scholar, the Web of Science and JSTOR with search terms "small", "municipality", "hamlet", and "capacity". This resulted in 50 empirical studies, which is a rather small number given the nature of the subject. We expected much more results, but research in the workings of small municipalities does seem to be a less popular subject among scholars than research in big municipalities.

In assessing the outcomes thereof, the same order as has been followed in the previous section orders also structures the findings in this section. It implies that we first give results from studies investigating the impact of con- 
textual conditions on small municipalities, then we present outcomes of existing research on the impact of structural conditions, subsequently previous research on institutional conditions is discussed, and lastly existing research on human resource conditions.

\subsection{Contextual conditions and small municipalities}

Research on the contextual conditions impacting on small municipalities was done by Ziółkowski (2015) on Poland. He argues that management is not only a decision-making process within structures of local self-government, but it is also an activity closely related to the environment. It means that management must be recognized in the context of changes that include parallel other processes like e.g., globalization of the economy, increasing competition among local government units on a regional, national and international scale, decentralization of public authority, introduction of new pro-efficiency solutions, membership in the European Union (p. 145).

Gabryjończyk and Iwańska (2010) studied Krzemienny Krag (Flint Circle Lag) and identified the most serious problems small municipalities face under changing contextual conditions. Through a survey among inhabitants of small communities, they found that every fourth respondent complained about the problem of finding a well-paid job, and lacking opportunities for individual development. Most respondents had a bad opinion about the access to roads, and the lack of cultural and entertainment facilities. Regarding economic development, one-third of the respondents pointed to the increase in numbers of village grocery stores. One-fifth of the respondents pointed to the development of agro-tourism, which became the general direction of entrepreneurship development in the region (p. 77). This research represents the interesting case of contextual conditions for the local development that requires participation of the whole local community in problem solving.

In Poland, in the result of the transition to a market economy and the EU accession, small municipalities can no longer base their activities solely on agriculture. It becomes less and less profitable, especially for small and non-specialized farms, having problems with lucrative sales of their products. Gabryjończyk and Iwańska (2010) emphasize that entrepreneurship becomes a new form of economic activity aiming at first to improve the socio-economic security of local inhabitants and later on, it could contribute to life improvement of the local community. They point out that, at the beginning, the development of non-agricultural activities was chaotic especially in small municipalities. With time, this trend proved to become better organized, formalized, and to support multifunctional rural development.

\subsection{Structural conditions and small municipalities}

As to the structural conditions of small municipalities, empirical research was done into issues involving the financial resources of small municipalities, e.g. Lorvi (2013, p. 98) argues that small municipalities have not been able to effectively exploit the possibilities many larger municipalities do have, such as 
making use of EU Structural Funds support, because their administrative capacity is weaker and their co-financing possibilities are insufficient. Instead Kriz, Paulus, and Staehr (2006) studied collecting local taxes. According to them, alternative forms of cooperation between municipalities in order to sustain service delivery, and differentiating the services to be delivered by small and large municipalities. Much of this research points out that amalgamations are not necessary, if small municipalities are willing to cooperate and to accept differentiation in tasks and authorities among municipalities.

That such willingness is not always self-evident, was shown by Previtali (2015). He investigated for Italy the administrative reform aiming at inter-municipal service agreements. Italy belongs to the locally fragmented countries. The author investigated 136 small municipalities from the Lombardy region that had 5,000 or less inhabitants. He focused on two types of inter-municipal cooperation: (1) "Unioni" of municipalities and (2) Inter-local service agreements with other small municipalities. The study showed what kind of joined public services the municipalities performed together, by what kind of agreement, and whether that varied with the size of municipalities. Their research concentrated on services such as records and information services, library, cemetery administration, electricity, parks and recreation, police, civil protection, finance, waste management, education, social, public works, city planning and traffic. It appeared that 37 of the 136 investigated small municipalities joined the so-called Unioni: The other 99 municipalities that declared that they did not join Unioni argued that they wanted "to avoid too deep linkages with other municipalities, which could become a restraint to their autonomy in the medium term" (p. 557) and that they wanted to protect their autonomy, traditions and habits.

Sometimes, cooperation is imposed by central government. In that case, small municipalities are forced to cooperate with one another and sometimes with a larger municipality. In Hungary, the government introduced "multi-purpose micro-regional associations", which can comprise up to 65 municipalities around a larger town in order to improve the structural conditions of municipalities. Such cooperation can take the form of multilevel contracts, in which the state and/or regional authorities cooperate with the municipalities under their jurisdiction. Vajdová, Čermák and Illner (2006) share the opinion that inter-municipal cooperation is also evident in the Czech Republic, where municipalities cooperate intensively, especially in the areas of regional development, tourism, environmental protection and in order to receive European subsidies, and somewhat less in social infrastructure, energy, transport and waste disposal. In Poland, municipalities have created regional, inter-regional and even international associations to cooperate. In 2004, in Slovakia, the very small municipalities had to choose to merge with other municipalities or intensify cooperation. For Italy, Fiorillo (2015) found that the capacity of a council to make its requests approved by central government is higher for a big council than for a small one.

An alternative is to differentiate functions according to municipal size. In Central and East European countries, public services are sometimes only provided by large cities e.g. in Georgia (cf, de Vries and Sobis, 2013). 
According to Mohr, Deller and Halstead (2010) small municipalities have many choices in providing public services and solving the structural issues involved. They could do it by themselves, they could sign an agreement with for-profit or not-for-profit contractors or enter in agreement with another local government or authority. The research concludes that small and rural municipalities, especially those that are isolated benefit from collaboration in providing various public services especially by signing external contracts. The authors argue that "collaboration is generating increased attention as a cost-saving, efficiency-enhancing option, especially if there are too few private suppliers to provide true competition" (p. 903). So, mutual supporting by neighbor municipalities is perceived as an adequate alternative for contracting private firms or non-profit agencies.

\subsection{Institutional conditions and small municipalities}

As to institutional conditions, research was done in the Czech Republic by Matějová, Plaček, Krápek, Puček and Ochrana (2014). The Czech Republic is a special case, because the number of small municipalities is huge. The country is characterized by high territorial fragmentation and the number of municipalities increased from 4120 in 1990 to 6250 in 2001 and stabilized afterwards (p. 404). The territorial fragmentation was said to be the major barrier for decentralization and for local government's effective functioning. Hence, the relationship between economic performance and size of municipality was frequently debated and became of pivotal importance for local government. The authors investigated if there is an optimal size for municipalities. They argued that "the economic rationales for decentralization in the public sector are frequently questioned by qualitative and quantitative research" (Matějová et al., 2014 p. 404) because of such elements as "spatial externalities, economies of scale, overall fiscal efficiency, regional equity, redistributive responsibilities of the government" (ibid., p. 404). In this research 5978 municipalities having 5000 or less inhabitants participated, constituting 95,63\% of all 6250 investigated municipalities. The normal cost curve proved to be U-shaped with the smallest and largest municipalities performing worst. Municipalities with very few inhabitants suffered regarding their preschool and primary functions, because of lacking facilities. Hence, it was not surprising that tiny communities advocated for "voluntary amalgamation of municipalities" to perform their functions (p. 409).

Satoła (2010) showed for Poland a general tendency of improvement regarding the financial results of the local government sector with size, manifesting itself as an increase in the share of own revenues and operating surplus in relation to total revenues. The analysis was conducted for the three-years period of 2006-2008, when the implementation of projects from the years 20042006 was completed and programs for the period of 2007-2013 started. His research was based on 1586 units with the status of a 'rural commune' (small rural municipalities) representing definitely lower level of financial independence in comparison to bigger municipalities. His conclusion was that, in order to be able to efficiently carry out tasks imposed on local governments, 
they must be equipped with financial power and that huge differences are observed among rural communes regarding their economic structure.

\subsection{Human resource conditions and small municipalities}

The insufficient expertise of personnel in small municipalities might impact on their ability to apply for higher government funding. However, Haček and Bačlija (2014), asked for the Slovenian municipalities how small localities cope with workload and whether they possess enough administrative capacity to provide public services for local community. Their finding was that independent of size, all municipalities have issues with their workload. Large municipalities are especially limited in providing additional services to citizens, while the smallest municipalities are overwhelmed with basic services. Hence, in both large and small municipalities the quality of public services provided can be questioned.

Large and small municipalities have different ways to deal with human resource problems. The small ones usually resolve this by hiring external consultants (Tatar, 2010, p. 210).

Although all over the world, many a study concludes that 'the lack of fully-employed managers hampers decision-making and the ability to strategically look forward' (cf. Development Bank of South Africa, 2009, p. 32). There is, however, an equal amount of studies pointing out that actually, very small municipalities have an advantage. Citizens in such municipalities know the administrators directly and personally and can control them on a daily basis, thus increasing the accountability (Fiorilllo, 2015, p. 3). Fiorillo also found that:

"(...) in small councils, the accountable relation between administrators and citizens is stronger than the one suggested by the idea that the control of citizens on politicians depends on voting as in models of fiscal federalism theory where accountability problem collapse in electoral decision and promises. [In hamlets] administrators have to consider not only costs depending on non-re-election but the costs of everyday claims" (p. 4).

\section{Findings out of comparative studies on municipalities}

Asking about the capacity of hamlets in a comparative way, one is immediately confronted with comparative capacity indexes. We also looked at such Local Capacity Indexes (LCI) as they are now widely available, for instance as constructed by the World Bank, the UN, and national agencies. The problem in using such LCl's is that although the number of indicators is huge, the indexes concentrate on the extensiveness of the organization, i.e. institutional and human resource dimensions of local capacity. It is about functional capacities, leadership, knowledge and accountability related to the organizational level, financial management; human resource management, career management, recruitment and promotion, dealing with incentives, process improvement, and additional areas of exploration, combined with engaging stakeholders, vision definition, formulating policies and strategies, budgeting, managing 
and implementation, and evaluation (cF. UN, 2012, p. 44ff). It is, for instance, about the capacity of municipalities to:

- Engage Stakeholders: Do authorities have the capacity to develop policies and legal and regulatory frameworks and mechanisms that ensure multi-stakeholder participation?

- Assess a Situation and Define Vision and Mandate: Do authorities have the capacity to frame, manage and interpret a comprehensive analysis of the policy and legal environment? Do authorities have the capacity to create a vision for fair and equitable policies and legal and regulatory frameworks and mechanisms?

- Formulate Policies and Strategies: Do authorities have the capacity to develop policy, legal and regulatory frameworks and mechanisms? And, do authorities have the capacity to develop policies and strategies relating to human resource development?

- Budget, Manage and Implement: Do authorities have the capacity to develop policy, legal and regulatory frameworks and mechanisms that support an integrated approach to budgeting and implementation? And, do authorities have the capacity to leverage human resources appropriately in the budgeting, management and implementation of programs and delivery of services?

- Evaluate: Do authorities have the capacity to develop policies and legal and regulatory frameworks and mechanisms for evaluation? And, do authorities have the capacity to evaluate performance and trends in HR capacity and productivity enhancement? (ibid.).

No matter how interesting such capacity assessment is, it is of little use for this study, as it is limited to the institutional and human resource dimensions of local capacity and it is only applicable for larger municipalities, as many of the criteria lose their meaning, if the municipality consists of only one or two administrators as is the case in very small municipalities. The number of functions and tasks distinguished in these indexes presume an extensive organization.

Instead of these indexes, we searched for a different proxy to understand the capacity of hamlets. Although far from ideal, we found such data in the Selfrule Index for Local Authorities (SILA) (Lender et al., 2015; 2016) and the outcomes of a Eurobarometer survey of 2016. As to the former, its final report states, this "project analyses 39 European countries and reports on changes in local autonomy between 1990 and 2014. A network of experts on local government assessed the autonomy of local government of their respective countries on the basis of a common code book. The eleven variables measured are located on seven dimensions and can be combined into a "Local Autonomy Index" (Lender et al., 2015, p. 2). The researchers distinguish different situations: 
- In a unitary country where all municipalities have the same degree of autonomy the unit of presentation is the country;

- In unitary countries with asymmetric arrangements there are different units of aggregation (for example: "municipalities in general" and "cities with special competences");

- In federal countries where all municipalities have the same degree of autonomy, the unit of presentation is the country;

- In federal countries where the degree of autonomy varies from one subunit to another, the units of aggregation are the subunits (Länder, cantons) (Lender et al., 2015, p. 14).

It is the fourth dot that makes using this index problematic to assess the capacity of small municipalities. The index does in the end fail to distinguish between the functions and autonomy of tiny, small, medium-size and large municipalities. For instance, for the Czech Republic, the most fragmented country in Europe regarding the number of municipalities, no distinction is made between the three categories used in the Czech Republic to distinguish between the 5017 "basic" municipalities, 1036 medium-size municipalities with delegated powers, and 205 municipalities with extended authorities and does not at all take the own responsibilities of municipalities into account. The same goes for France, for which this database tells that it is the most decentralized country with a maximum of policy areas for which municipalities - in fact the departments - are responsible.

Regarding the contextual level, the SILA only distinguishes degrees of legal protection - defined as the existence of constitutional or legal means to assert local autonomy. As to the structural dimension of local capacity in which intergovernmental relations are central, SILA distinguishes the extent of central or regional access - defined as the extent to which local authorities are consulted to influence higher level governments' policymaking. As to the institutional dimension of local capacity, this project distinguishes between policy scopes - defined as the range of functions (tasks) where local government is effectively involved in the delivery of the services and organizational autonomy - defined as the extent to which local government is free to decide about its own organization and electoral system.

Nonetheless, and although we immediately acknowledge that autonomy is different from capacity, some of the indicators used in the project do provide proxies for all the dimensions of local capacity but one, we distinguished before is lacking. SILA does not provide indicators on the human resource dimension of local capacity. Therefore, we searched for this indicator from another source, that is Eurobarometer data, to investigate the trust in local authorities and compare this for countries with many small municipalities and countries in which there are only large municipalities. Trust is defined in terms of encapsulated interests - do authorities take the interests of the residents into account, when making decisions and are they capable of doing what they are supposed to do (Hardin, 2002; de Vries and Sobis, 2018). If either of the two is lacking, one cannot be expected to trust the authorities, just as one 
wouldn't trust a babysitter, if this person either would not take the interests of the baby into account in the decision-making, or would not be capable to babysit. Hence, trust in local authorities is seen as a proxy for the capacity of local government within the human resource dimension (cf. de Vries and Sobis, 2018). We measured the trust in local and regional authorities using the outcomes of the Eurobarometer survey of 2017/1. We selected respondents living in localities of 2,000 people or less, that were living in small localities, and analyzed their answers to the question in relation to the size of the community they live in". This is indicative for the trust in the local authorities of people living in rural areas. The analysis enables a comparison between countries where municipalities are on average small and every community has its own municipality, and countries where the average size of municipalities is larger and local authorities are more distant from the villagers.

Such analyses need to be controlled for contextual factors, as in Europe, trust in authorities is strongly related to wealth, living in one of the CEE countries or in Western Europe. Table 1 below provides information about this association ( $\mathrm{N}=39$ European countries). The table shows that trust in local authorities is strongly related to the wealth of the country (GDP per capita) $\left(R^{2}=-0.650\right)$ and is much higher in Western Europe than in CEE countries $\left(R^{2}=-0.421\right)$.

Table 1: Trust in local authorities and its determining factors (PM Correlations)

\begin{tabular}{lrrrr} 
& $\begin{array}{c}\text { Trust in local } \\
\text { authorities }\end{array}$ & $\begin{array}{c}\text { GDP per } \\
\text { capita }\end{array}$ & CEE \\
\hline Trust in local authorities & 1 &, $650^{* *}$ &,$- 421^{*}$ \\
\hline GDP per capita &, $650^{* *}$ & 1 &,$- 589^{* *}$ \\
\hline CEE &,$- 421^{*}$ &,$- 589^{* *}$ & 1
\end{tabular}

Therefore, our analysis proceeds as follows. First, we create two groups, namely CEE-countries and Western European countries. Within these two groups we distinguish countries based on their municipality density, that is, the average number of inhabitants per municipality. Subsequently, we analyze whether the scores on the four dimensions are related to this municipality density. The analysis of these data will out of necessity be at an aggregated, national, level, as more specific data on the local level are unavailable. It will also be descriptive, as multivariate modeling is hardly possible given the distribution of the variables. We investigated whether the main variables used in this research, "municipal density", "trust in small municipality authorities", "access of municipalities to central and regional decision making", and "policy scope" have a statistically normal distribution. This is necessary for a regression analysis, but only seems to be the case for "policy scope". Municipal density is very skewed to the left with half the countries having less than 
10,000 residents per municipality, while the average size of municipalities in other countries varies between 20,000 and nearly 60,000 . Trust is skewed to the right, as is access to regional and central decision making. All this makes a regression analysis with trust in local authorities perilous.

Therefore, this analysis is done on the basis of the descriptive values on the different variables in different countries. This does not alter the research question, namely to what extent judicial protection, access to regional and national decision-making, the policy scope, and the trust in local authorities co-vary with the average size of municipalities in Western and Central European countries.

The validity and reliability of the data derived from the Local Autonomy Index and the Eurobarometer can be disputed. National experts could even totally disagree with the figures given. Firstly, the data are aggregated proxies. To measure local capacity at an aggregated - national level is perilous. The authors are the first to acknowledge the issues at stake. Furthermore, is trust in local authorities indeed the best indicator for the human resource dimension of local capacity? In theory the indicator is valid as capacity is a core element in the definition of trust, but in the practice of answering a survey question, the answers could as well imply the opinion about the trustworthiness of local authorities irrespective of their capacity to accomplish things for the municipality. Also, we acknowledge that the contextual dimension of local capacity involves more than only its legal protection, that intergovernmental relations - the structural dimension - involve more than regional and national access of municipalities, and that the institutional dimension involves more than the scope of functions and the freedom to decide about one's own organization. A further objection could be that some indicators do not differentiate between the capacity of small and large municipalities in a country. The access to regional and national decision-making is often equal for all municipalities. Below, we determine whether such access is better or worse guaranteed in countries consisting of many small municipalities compared to countries where there are hardly small municipalities. It does not tell whether small municipalities have more or less access than large municipalities in a country, but it does ascertain whether and to what extent the potential capacity of small municipalities to influence decisions made at the regional and national level is guaranteed in countries with many small municipalities, compared to countries in which small municipalities are (almost) absent. All such objections are justified, and imply that much more research into the issues involved is needed, and that the outcomes as presented in the next section are not definitive, as they provide just a preliminary insight in the capacity of small municipalities. In fact, one could say that the data used are more indicative for the potential capacity of small municipalities than for the actual capacity thereof. If the viability of municipalities is strongly supported in the constitution of a country, if their access to the decision-making at higher levels is guaranteed, if the scope of policies they are responsible for themselves is limited, and if their residents trust their local governments more if they are nearby i.e. smaller, this is indicative for their potential capacity. 


\section{Outcomes}

In this section, we discuss how the size of municipalities relates to the contextual, structural, institutional and human resource conditions as distinguished above. First, we give some descriptive outcomes on municipal density, that is, the average number of residents in municipalities in different countries. Figure 1 gives the differences between countries.

It is seen that the Czech Republic has on average the least number of residents per municipality, followed by France, the Slovak Republic, Cyprus, Hungary, Moldova, Ukraine, Liechtenstein, Austria, Switzerland, Iceland, Luxembourg, Spain, Estonia, Malta and Germany. At the other end of the spectrum one can see Denmark, Ireland, Turkey, Georgia, Albania and Lithuania with relatively many residents per municipality. The latter are all countries in which major processes of consolidation have taken place during the last decade.

Figure 1: Average no of residents (x1000) per municipality

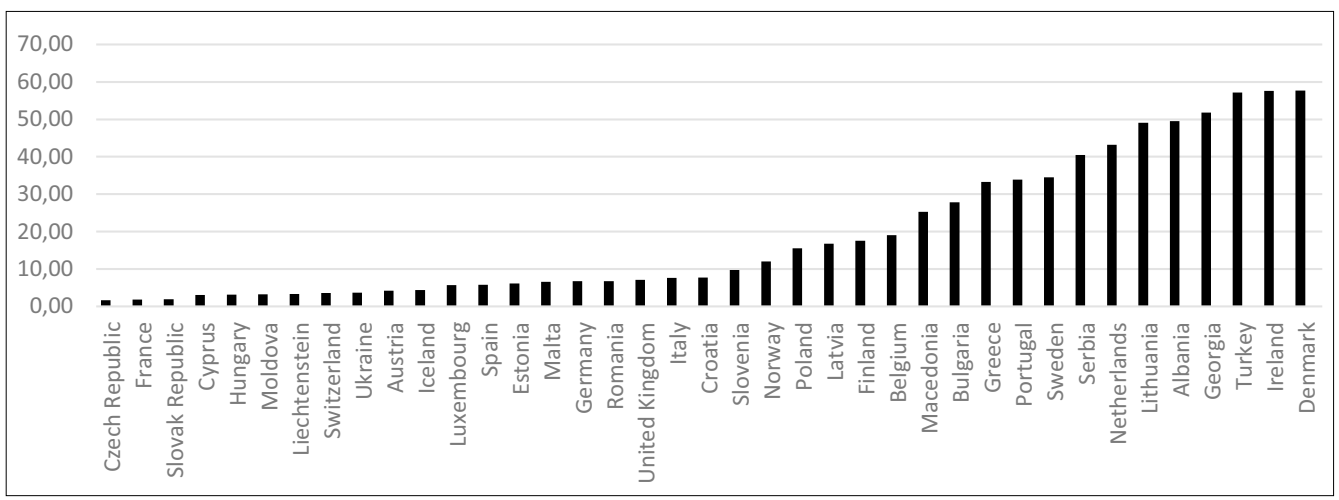

The question is how this relates to the four capacity conditions. As to legal protection, the Czech Republic, Liechtenstein, Switzerland, and France - all countries in which many hamlets still exist, all get a maximum score, implying that there exist constitutional or legal means to assert local autonomy. In these countries the laws and constitution protect local autonomy such as e.g. listing of all municipalities in the constitution or the impossibility to force them to merge, and countries like the Slovak Republic, Cyprus, Slovenia, Austria and Hungary get a lower score. Among the countries such as Denmark, Turkey, and Ireland, in which many amalgamations recently occurred, such legal protection is nearly absent (cf. Lender et al., 2015, p. 50). 
Figure 2: Access to central and regional decision-making

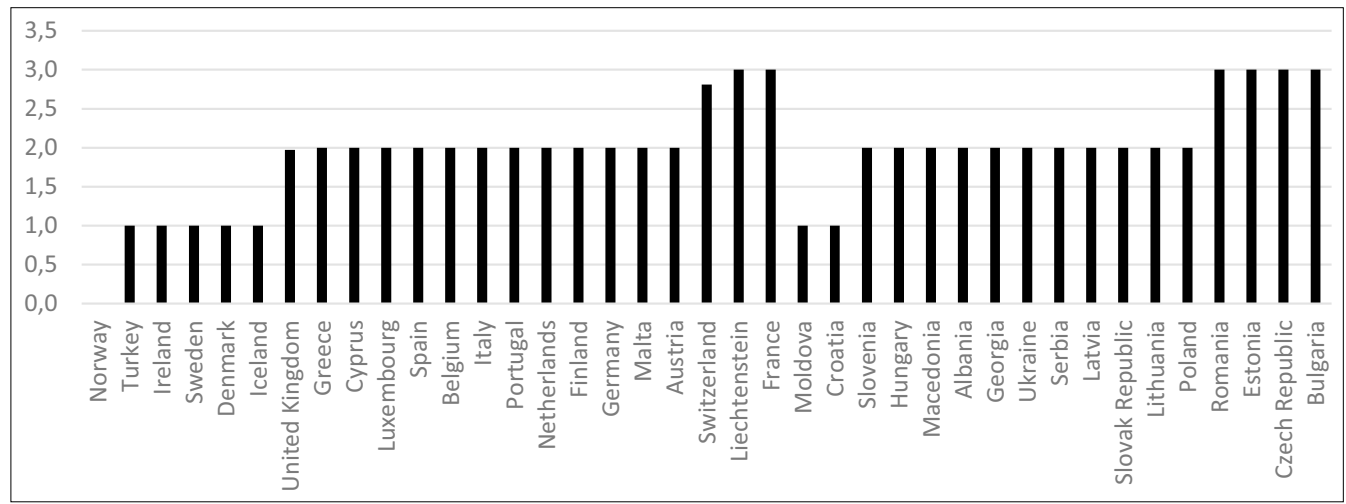

A re-analysis of the figures by Lender et al., also shows that in those countries where most micro-municipalities exist, the access of those municipalities to central and regional decision-making is largest. This is seen in Western Europe in France, Liechtenstein, and Switzerland, and in CEE-countries in Bulgaria, the Czech Republic and Estonia. The countries in which such access is smallest are those where huge amalgamations took place, that is Turkey, Ireland, Sweden and Denmark in the West, with Iceland being an exception, and Moldova and Croatia in CEE-countries.

Figure 3: Policy scope of municipalities

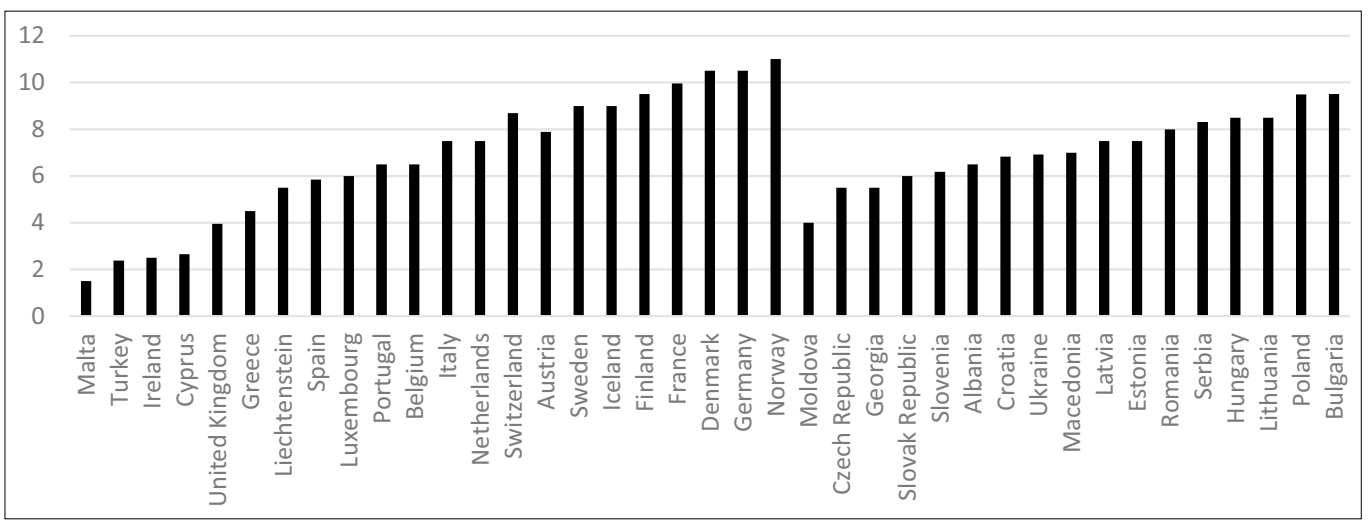

As to the policy areas taken care of by the regions, the SILA database distinguishes 13 policy areas and measures whether municipalities have responsibilities in those areas. We counted the number of policy areas for which municipalities have responsibilities in a country, resulting in a scale from 0-13. The results are given in figure 2 . The figures show that in countries in the CEE-region with many small municipalities, the number of functions is most limited -Moldova, Czech Republic, Georgia, while the number of functions is largest in countries where amalgamations have taken place, i.e. Lithuania, Poland and Bulgaria. 
Figure 4: Trust in local authorities

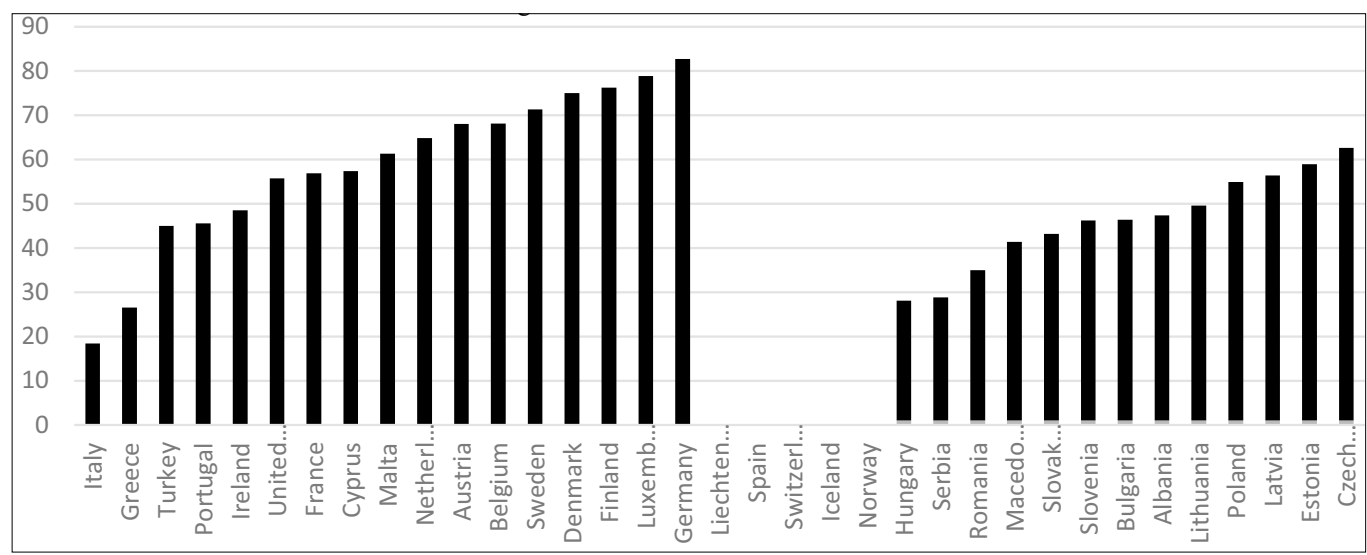

Figure 3 is based on the opinions of people living in the smallest areas $(<2000$ inhabitants in their locality). It shows that these people on the whole, trust local authorities most in those countries which have most small municipalities. In CEE-countries, this applies to the Czech Republic, having mostly very small municipalities. It is also in the Czech Republic that most of the people living in the rural areas express their trust in the local authorities. In Western Europe this is seen in Germany with its many small "Gemeinde" and Luxemburg. Although an analysis of the data does not show a strong linear relation between municipal density and the trust of rural people in local authorities, the outcomes do indicate that such trust is especially high in those countries where the local authorities are still closest to the people, i.e. the hamlets.

\section{Conclusions}

This paper asked what is known from existing research about the capacity of small municipalities? In order to answer that question, we posed four sub-questions, namely:

1. What is local government capacity?

2. Which impact have conditions of size on local capacity in theory?

3. What trends emerge out of case studies on small municipalities?

4. What can be concluded about the local capacity of small municipalities analyzing comparative data?

As to sub-question 1, we defined local government capacity as "the ability of local government to perform their functions in an effective and efficient way". It is not about the amount of functions, the budget or the number of officials employed, which would be inherently favoring big municipalities and disadvantage the small ones. Even municipalities with only a few functions, a low budget and little personnel can have sufficient capacity to do effectively and efficiently what they are supposed to do. Of course, such capacity depends on a number of factors. These were identified as contextual conditions, structural conditions, institutional conditions and human resource conditions. 
The existing literature is far from unanimous in its conclusions on the capacity of small municipalities compared to their larger counterparts. The results of a literature review revealed that unequivocal conclusions about the capacity of hamlets and the impact of each of the four conditions thereon are severely missing. Indeed, there is not an abundance of research on small municipalities. Some of the scarce scholars investigating the issues involved find negative effects of municipality's small size, while others point to the merits thereof. This knowledge is not increased by comparative data as provided by the nowadays popular "Local Capacity Indexes". The indices used to measure local capacity in those indexes make it an instrument that is perhaps valid for measuring the capacity of big municipalities, but not for small municipalities, let alone, hamlets. Using the criteria dominant in those local capacity indexes, results in the outcome that small municipalities are by definition less capacitated compared to bigger municipalities. This is the case, as the availability of resources and personnel is crucial in those indices and hamlets by definition have a minimum of resources and personnel and never will suffice to fulfil all the criteria such indexes use to score local capacity. As there is not much more empirical data, the answer to our main research question cannot but be that we simply don't know much about the actual capacity of hamlets. This is a striking conclusion, since in many countries in Western Europe as well as in CEE-countries witnessed huge consolidation processes in the last decade, out of the idea that the capacity of small municipalities is insufficient.

Some countries escaped such merger processes. Very small municipalities are nowadays still to be found in the Czech Republic, France, the Slovak republic, Cyprus, Hungary, Moldova, Ukraine, Liechtenstein, Austria, Switzerland, Iceland, Luxembourg, Spain, Estonia, Malta and Germany. In many of these countries such small municipalities thank their survival to the legal protection they enjoy. In Western Europe this is especially visible in France, Switzerland and Liechtenstein in their constitutions. In CEE-countries the Czech Republic, Bulgaria and Estonia are exemplary in this regard. In Western Europe main examples of consolidation processes being enabled by the absence of legal protection of municipalities are Turkey, Ireland, Sweden, and Denmark, where huge amalgamations have recently been enacted. Contextual conditions such as legal protection in national laws do capacitate small municipalities to survive.

As to the structural conditions, in countries with many hamlets, the access of those municipalities in central and regional decision-making seems significantly larger than in countries with amalgamated municipalities. This seems to be related to the limited number of functions small municipalities have in comparison to large municipalities. In terms of multilevel governance there seems to be a tradeoff between the functions of a municipality (determined partly by its size) and the access to the decision-making at higher levels of government. This is most clearly seen in the Nordic countries (Denmark, Sweden, and Ireland) and in Turkey in which amalgamations have taken place, and simultaneously their access in higher level decision-making processes has disappeared. 
This research found that the main asset of small municipalities is the trust they generate from their residents. Our analyses show that residents of rural communities in countries within which still many hamlets exist and thus the distance between those residents and their authorities is small, trust their local authorities more, than residents in rural areas where the hamlets have been disappeared and the local authorities are more distant from their rural residents.

One could object to the outcomes by pointing out that the findings are not indicative for the actual capacity of hamlets. Indeed, the authors agree that the indicators are disputable and we urge researchers to conduct comparative analyses. Although we do agree that the indicators vary in their validity to make any claim about the actual capacity of hamlets, we do judge the measures useful as indicators for the potential capacity of small municipalities. Especially in their combination - having the trust of the residents, having guaranteed access to decision-making at the regional and national level, being protected by law, and not having to bother with all those policy areas outside their capacity - these measures are seen as proxies for potential capacity.

The main conclusion is therefore, that although information is severely missing about the actual capacity of small municipalities and any answer to the question about their actual capacity is precarious, our comparative analysis points out that the potential capacity of small municipalities is far from negligible. This goes counter to argumentation underlying the amalgamation processes that have taken place in many a European country and is a warning that such amalgamation processes could have serious side-effects. 


\section{References}

Bhatti, Y. and Hansen, K. M. (2011). Who 'marries' whom? The influence of societal connectedness, economic and political homogeneity, and population size on jurisdictional consolidations. European Journal of Political Research, 50(2), pp. 212-238.

Boyne, G. A. (1995). Population Size and Economies of Scale in Local Government. Policy and Politics, 23, pp. 213-222.

Brans, M. (1992). Theories of local government reorganization: an empirical evaluation. Public Administration, 70(3), pp. 429-451.

Carter, M. (2013). Briefing Paper: Australian local government financial reform - A federal perspective. Camberra: ANZSOG Institute of Governance and ACELG, Sydney: University of Technology. At <https://www.uts.edu.au/sites/ default/files/2013-ACELG_Briefing_paper_Financial_Sustainability.pdf> accessed 30 March 2018.

Dahl, R. A., and Tufte, E. (1973). Size and democracy. Stanford, CA: Stanford University Press.

Davey, K. (ed.) (2012). Local Government in Critical Times: Policies for Crisis, Recovery and a Sustainable Future. Council of Europe texts, 2011. Strasbourg: Council of Europe, Centre of Expertise for Local Government Reform.

Denters, B., Goldsmith, M., Ladner, A., Mouritzen, P. E. and Rose, L. E. (2014). Size and local democracy. Cheltenham: Edward Elgar.

Development Bank of South Africa. (2009). Knowledge week 09: Making Local Government work better. Midrand, DBSA.

Fiorillo, F. (2015). Small local governments between Scilla and Carriddi. Incentives for territorial reform. Universita` Politecnica delle Marche. Paper presented at XXXVI AISRE Conference.

Fox, W. F. and Gurley-Calvez, T. (2006). Will Consolidation Improve Sub-National Governments? (Policy Research Working Paper No. 3913). Washington, DC: World Bank.

Gabryjończyk, P. and Iwańska, M. (2010). Stan i kierunki rozwoju przedsiebiorczości na obszarze lokalnej grupy działania 'Krzemienny Krag'. Acta Scientarium Polonorum Oeconomia, 9(2), pp. 71-82.

Haček, M. and Bačlija, I. (2009). The Administrative Capacity of Slovenian Municipalities. Lex Localis - Journal of Local Self-Government, 7(3), pp. 307-327.

Hardin, R. (2002). Trust and trustworthiness. Russell Sage Foundation.

Kersell, J. E. (1987). Authorities administration in a small microstate: Developing the Cayman Islands. Public Administration and Development, 7(1), pp. 95-107.

Kjellberg, F. (1985). Local government reorganization and development of welfare state. Journal of Public Policy, 5(2), pp. 215-239.

Kriz, K. A., Alari, P. and Staehr, K. (2006). User Charges and Fees: The Estonian Case. In Z. Šević, ed., Local Government Non-Tax Revenue Sources in Transition Countries: User Fees and Charges 48. Bratislava: NISPAcee, pp. 104-130.

Lender, A., Keufer, N. and Baldersheim, H. (2015). Self-rule Index for Local Authorities. Brussels: European Commission, Directorate-General for Regional and Urban Policy. At <http://ec.europa.eu/regional_policy/sources/ docgener/studies/pdf/self_rule_index_en.pdf > accessed 4 April 2018.

Lender, A., Keufer, N. and Baldersheim, H. (2016). Measuring Local Autonomy in 39 countries (1990-2014). Regional and Federal Studies, 26(3), pp. 321-357. 
Lindblom, C. E. and Cohen, D. K. (1979). Usable knowledge: Social science and social problem solving. 21. Yale University Press.

Lorvi, K. (2013). Unpacking Administrative Capacity for the Management of EU Structural Funds in Small and Large Municipalities: The Estonian Case. Halduskultuur - Administrative Culture,14(1), pp. 98-124.

Matějová, L., Plaček, M., Krápek, M., Puček, M. and Ochrana, F. (2014). Economies of scale - empirical evidence from the Czech Republic. Procedia Economics and Finance, 12, pp. 403-411.

Mohr, R., Deller, S. C. and Halstead, J. M. (2010). Alternative methods of service delivery in small and rural municipalities. Public Administration Review, November, pp. 894-905.

Murray, D. J. (1981). Microstates: public administration for the small and beautiful. Public Administration and Development, 1(4), pp. 245-256.

Previtali, P. (2015). The Italian administrative reform of small municipalities: state-of the-art and perspectives. Public Administration Quarterly, 39(4), pp. 548-568.

Reddy, P. S., Nemec, J. and de Vries, M. S. (2015). The state of local government. Public Policy Administration/Viešoji politika ir administravimas, 14(3), pp. 160-176.

Satoła, Ł. (2010). Ocena sytuacji finansowej gmin wiejskich w Polsce w latach 2006-2008. Acta Scientarium Polonorum Oeconomia, 9(2), pp. 199-210.

Tatar, M. (2010). Estonian Local Government Absorption Capacity of European Union Structural Funds. Halduskultuur - Administrative Culture, 11(2), pp. 202-226.

United Nations (UN). (2012). Local Governments in Southern Africa: An Analytical Study of Decentralization, Financing, Service Delivery and Capacities. New York: UNDP.

Vajdová, Z., Čermák, D. and Illner, M. (2006). Autonomie a spolupráce: důsledky ustavení obecního zřízení v roce 1990. Sociologické studie, 2. Praha: Sociologický ústav AV ČR.

Vries, M. S. de and Sobis, I. (2013). Consolidation in local government: An international comparison of arguments and practices. Journal of the Institute of Public Administration of Ireland, 61(3), pp. 31-50.

Vries, M. S. de and Sobis, I. (2018). Trust in the Local Administration: A Comparative Study between Capitals and Non-Capital Cities in Europe. NISPAcee Journal of Public Administration and Policy, 11(1), pp. 209-228.

Wallis, J. and Dollery, B. (2002). Social capital and local government capacity. Australian Journal of Public Administration, 61(3), pp. 76-85.

Wollmann, H. (2004). Local government reforms in Great Britain, Sweden, Germany and France: between multi-function and single-purpose organisations. Local Government Studies, 30(4), pp. 639-665.

Wollmann, H. (2012). Local Government Reforms in (Seven) European Countries: Between Convergent and Divergent, Conflicting and Complementary Developments. Local Government Studies, 38(1), pp. 41-70.

Ziółkowski, M. (2015). Strategiczne zarzadzanie rozwojem gminy. Ruch Prawniczy, Ekonomiczny i Socjologiczny, Rok LXXVII, Zeszyt 1, pp. 145-163. 